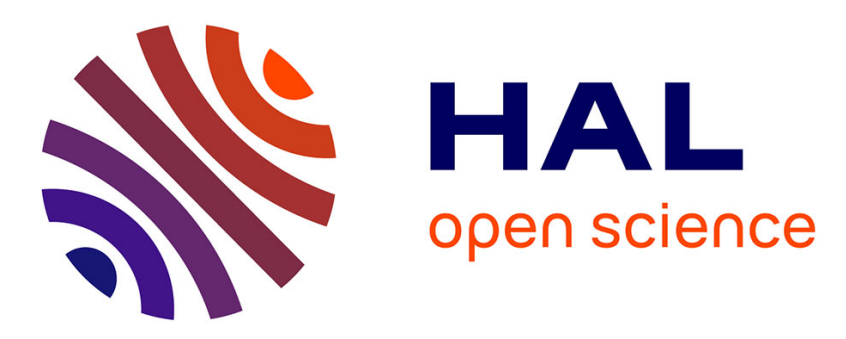

\title{
MUSIC imaging method for low-high frequency inspection of composite multi-layers
}

Giacomo Rodeghiero, Ping-Ping Ding, Yu Zhong, Marc Lambert, Dominique Lesselier

\section{- To cite this version:}

Giacomo Rodeghiero, Ping-Ping Ding, Yu Zhong, Marc Lambert, Dominique Lesselier. MUSIC imaging method for low-high frequency inspection of composite multi-layers. QNDE 2014, Jul 2014, Boise, United States. pp.453-461, 10.1063/1.4914641 . hal-01101599

\section{HAL Id: hal-01101599 \\ https://hal-centralesupelec.archives-ouvertes.fr/hal-01101599}

Submitted on 9 Jan 2015

HAL is a multi-disciplinary open access archive for the deposit and dissemination of scientific research documents, whether they are published or not. The documents may come from teaching and research institutions in France or abroad, or from public or private research centers.
L'archive ouverte pluridisciplinaire HAL, est destinée au dépôt et à la diffusion de documents scientifiques de niveau recherche, publiés ou non, émanant des établissements d'enseignement et de recherche français ou étrangers, des laboratoires publics ou privés. 
Session/Topic area: modeling, simulations, signal processing, NDE applications

\title{
MUSIC imaging method for low-high frequency inspection of composite multi-layers
}

\author{
Giacomo RODEGHIERO ${ }^{*}$, Ping-Ping DING ${ }^{1}, \mathrm{Yu} \mathrm{ZHONG}^{2}, \mathrm{Zarc} \mathrm{LAMBERT}^{1}$, and \\ Dominique LESSELIER ${ }^{1}$
}

${ }^{1}$ Département de Recherche en Electromagnétisme - Laboratoire des Signaux et Systèmes UMR8506 CNRS-SUPELEC-Univ. Paris Sud, 3 rue Joliot-Curie, 91192 Gif-sur-Yvette, France

${ }^{2}$ A*STAR, Institute of High Performance Computing, 138632 Singapore

\begin{abstract}
THIS PAPER IS SUBMITTED AS STUDENT POSTER.
\end{abstract}

Non-destructive Testing-Evaluation (NdT-E) of damaged multi-layer structures like fiber-made composite materials involved in aeronautic and automotive industries is a topic of great interest to solve problems of viability and security.

From eddy currents to test graphite-based materials to microwaves and beyond to test glass-based composite structures, one aims to obtain images of the possibly damaged parts with robust, fast inversion algorithms. In this contribution, such algorithms are tailored to detect small (compared to the local wavelength in propagative regime or skin depth in diffusive regime) inclusions affecting the structures mentioned above. These inclusions may be voids, fluid-filled cavities (i.e., isotropic) or even uniaxial ones. Yet this requires proper models of the layerings to compute their response due to electromagnetic sources, notably electric dipoles or magnetic coils.

Based on [1-2], it is proposed herein a method to compute in an effective fashion the dyadic Green's functions (DGF) for such structures within the framework of contrast-source integral equations. Special care is taken when the sources are far away from the origin, yielding an oscillating spectrum of the DGF. The Multiple Signal Classification (MUSIC) imaging method [3], which uses such DGF, is applied to find the position of small defects. Possible application of MUSIC for structure delaminations is treated also.

\section{References}

[1] Y. Zhong et al., "Electromagnetic response of anisotropic laminates to distributed sources", IEEE Trans. Antennas Propag., 62 (2014), pp. 247-2560.

[2] G. Rodeghiero et al., "An efficient interpolation for calculation of the response of composite layered material and its implementation in MUSIC imaging”, COMPUMAG 2013 Conf., Budapest, June.

[3] H. Ammari et al., "MUSIC-type electromagnetic imaging of a collection of small three-dimensional inclusions", SIAM Journal of Scientific Computing 29 (2007), pp. 674-709.

\footnotetext{
* Corresponding author. E-mail address: giacomo.rodeghiero@1ss.supelec.fr
} 